\title{
SYNTHESES OF AZO-IMINE DERIVATIVES FROM VANILLIN AS AN ACID BASE INDICATOR
}

\author{
Bambang Purwono ${ }^{1, *}$, Chairil Anwar ${ }^{1}$, and Ahmad Hanapi ${ }^{2}$ \\ ${ }^{1}$ Department of Chemistry, Faculty of Mathematics and Natural Science, Universitas Gadjah Mada, \\ Sekip Utara, Yogyakarta 55281 \\ ${ }^{2}$ Department of Chemistry, Faculty of Science and Technology, UIN Maulana Malik Ibrahim, Malang
}

Received November 13, 2012; Accepted March 17, 2013

\begin{abstract}
Preparations of azo, imine and azo-imine derivatives from vanillin as an indicator of acid-base titration have been carried out. The azo derivative of 4-hydroxy-3-methoxy-5-(phenylazo)benzaldehyde 2 was produced by diazotitation reaction of vanillin in $37.04 \%$ yield. The azo product was then refluxed with aniline in ethanol to yield azo-imine derivatives, 2-methoxy-6-(phenylazo)-4-((phenylimino)methyl)phenol 1 in $82.21 \%$ yield. The imine derivative, 2-methoxy-4-((phenylimino)methyl)-phenol 3 was obtained by refluxing of vanillin and aniline mixture in ethanol solvent and produced $82.17 \%$ yield. The imine product was then reacted with benzenediazonium chloride salt. However, the products indicated hydrolyzed product of 4-hydroxy-3-methoxy-5-(phenylazo)benzaldehyde 2 in $22.15 \%$ yield. The 2-methoxy-4-((phenylimino)methyl)phenol 2 could be used as an indicator for titration of $\mathrm{NaOH}$ by $\mathrm{H}_{2} \mathrm{C}_{2} \mathrm{O}_{4}$ with maximum concentration of $\mathrm{H}_{2} \mathrm{C}_{2} \mathrm{O}_{4} 0.1 \mathrm{M}$ while the target compound 1 could be used as titration indicator for titration of $\mathrm{NaOH}$ with $\mathrm{H}_{2} \mathrm{C}_{2} \mathrm{O}_{4}$ with same result using phenolphthalein indicator.
\end{abstract}

Keywords: vanillin; indicator of acid-base titration; azo-imine group

\section{ABSTRAK}

Telah dilakukan sintesis turunan senyawa azo, imina dan azo-imina dari vanilin sebagai indikator titrasi asambasa. Sintesis turunan azo, 4-hidroksi-3-metoksi-5-(fenilazo)benzaldehida 2 dilakukan dengan reaksi diazotasi vanilin dengan rendemen $37,04 \%$. Produk azo selanjutnya direfluks dengan anilina dalam pelarut etanol menghasilkan turunan azo-imina, 2-metoksi-6-(fenilazo)-4-((fenilimino)metil)fenol 1 dengan rendemen 82,21\%. Sintesis turunan imina dilakukan dengan merefluks campuran vanilin dan anilina dalam pelarut etanol menghasilkan 2-metoksi-4-((fenilimino)metil)fenol 3 dengan rendemen 82,17\%. Produk imina selanjutnya direaksikan dengan garam benzenadiazonium klorida. Namun produk yang terbentuk adalah produk hidrolisis 4-hidroksi-3-metoksi-5(fenilazo)benzaldehida 2 dengan rendemen 22,15\%. Senyawa 2-metoksi-4-((fenilimino)metil)fenol dapat dijadikan sebagai indikator untuk titrasi $\mathrm{NaOH}$ oleh $\mathrm{H}_{2} \mathrm{C}_{2} \mathrm{O}_{4}$ dengan konsentrasi maksimum $\mathrm{H}_{2} \mathrm{C}_{2} \mathrm{O}_{4} \mathrm{O}, 1 \mathrm{M}$, sedang senyawa target mempunyai hasil yang sama dengan menggunakan indikator fenolftaline.

Kata Kunci: vanillin; indikator titrasi asam-basa; gugus azo-imin

\section{INTRODUCTION}

Recently, attempts to synthesize for acid-base titration indicator from the natural products of phenol has become our concerns [1] The indicator compounds from phenol natural product compounds have been obtained by extending of delocalization of electron through chromophoric group [2]. The investigation also showed the increases in the visible absorption through the addition of base and acid. We were interested to introduce azo and imine groups together into vanillin as a targeted compound 1 . The azo derivatives have been used for dyes synthesis [3,4], metal ion sensor [5] and $\mathrm{pH}$ measurement [6]. The imine derivatives have been

* Corresponding author. Tel/Fax : +62-274-545 188

Email address : purwono.bambang@ugm.ac.id used for pigments [7], titration indicator [8] and fluorometry reagent [9].

The target compound 1 would be synthesized by two routes. First route, the aldehyde group in vanillin is converted to imine derivative by Schiff-base imine formation and then reacted diazotization with benzenediazonium ion [10]. The second route, vanillin is reacted by benzenediazonium ion and then converted to imine derivatives. All of imine, azo and imine-azo product derivatives contain chromophoric group. They will be examined the change in the color of solution through the addition of base and acid.

In this paper, the targeted compound $\mathbf{1}$ is subjected to examine stabilization in acid and base. The 


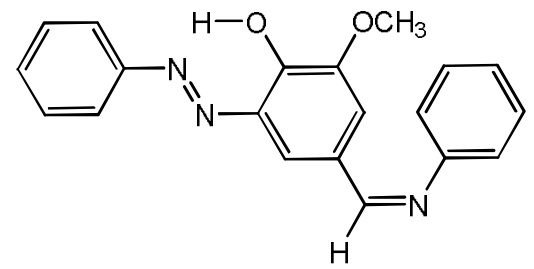

Fig 1. The structure of the designed potential acid-base titration indicator (1)

azo group indicates stabilization in acid and base condition while the imine could be hydrolyzed in base condition [11]. Such phenomenon is unexpected for indicator compounds. Therefore, it seems quite challenging to observe the study of their acid-base equilibrium in order to establish whether it could be used as an acid-base indicator.

\section{EXPERIMENTAL SECTION}

\section{Materials}

All reagents and solvents were purchased from E.Merck, unless otherwise specified. The materials used in this study were: vanillin, aniline, $\mathrm{HCl} 37 \% \mathrm{w} / \mathrm{v}, \mathrm{NaNO}_{2}$, $\mathrm{NaOH}, \mathrm{CHCl}_{3}, \mathrm{NaHCO}_{3}, \mathrm{Na}_{2} \mathrm{SO}_{4}$ anhydrous, ethanol, phenolphthalein indicator, $\mathrm{KH}_{2} \mathrm{PO}_{4}, \mathrm{Na}_{2} \mathrm{HPO}_{4}$, silica gel 60 (0.040 to $0.063 \mathrm{~mm}$ ), buffer solution $\mathrm{pH} 2$ to 13 .

\section{Instrumentation}

Infrared spectra were recorded with Shimadzu Prestige-21FTIR Spectrophotometer. ${ }^{1} \mathrm{H}$-NMR spectra were recorded on JEOL JNM-MY60 spectrometer. Mass spectra were performed on Shimadzu QP-QP-5000 and 2010. Melting point was recorded with uncorrected Electrothermal-9100.

\section{Procedure}

\section{Synthesis of 4-hydroxy-3-methoxy-5-(phenylazo) benzaldehyde (2)}

Aniline $(1.49 \mathrm{~g}, 16 \mathrm{mmol})$ was dissolved in a mixture of $\mathrm{HCl} 37 \% \mathrm{w} / \mathrm{v}(4.73 \mathrm{~mL}, 48 \mathrm{mmol})$ and distilled water $(4.73 \mathrm{~mL})$ in beaker glass $250 \mathrm{~mL}$. The solution was cooled in an ice bath until a temperature to $0-5{ }^{\circ} \mathrm{C}$. $\mathrm{NaNO}_{2}(1.21 \mathrm{~g}, 17.6 \mathrm{mmol})$ was dissolved in aquadest $(6 \mathrm{~mL})$ and chilled in an ice bath. The solution of $\mathrm{NaNO}_{2}$ was added dropwise into the solution of aniline- $\mathrm{HCl}$, stirring and temperature maintained at $0-5{ }^{\circ} \mathrm{C}$ to produce benzenediazonium chloride salt solution. The solution was kept for several minutes with the temperature maintained at $0-5{ }^{\circ} \mathrm{C}$. Vanillin $(2.43 \mathrm{~g}$, $16 \mathrm{mmol}$ ) was dissolved in $\mathrm{NaOH}$ solution $10 \%(\mathrm{w} / \mathrm{v})$ $(7.5 \mathrm{~mL})$. The solution was cooled in an ice bath until a temperature of $0-5 \quad{ }^{\circ} \mathrm{C}$. Solution of cooled benzenediazonium chloride was added slowly to the solution of sodium-vanillin, stirring constantly until it forms a gel. The gel was then separated by extraction using chloroform $(3 \times 25 \mathrm{~mL})$ and the organic layer was neutralized with $\mathrm{NaHCO}_{3}$ solution. The organic layer was dried with anhydrous $\mathrm{Na}_{2} \mathrm{SO}_{4}$. The solvent of chloroform was evaporated with Büchi evaporator and residue was purified by using column chromatography with silica gel absorbent and chloroform eluent. After evaporating of the chloroform eluent, product was obtained as red solid, yield $37.04 \%$, m.p. $132-133^{\circ} \mathrm{C}$. IR cm ${ }^{-1}: 3425 \quad(\mathrm{O}-\mathrm{H}) ; 3055 \quad\left(\mathrm{C}_{\mathrm{sp} 2}-\mathrm{H}\right.$ aromatic); $2931\left(\mathrm{C}_{\mathrm{sp} 3}-\mathrm{H}\right) ; 1674(\mathrm{C}=\mathrm{O}) ; 1604(\mathrm{C}=\mathrm{C}$ aromatic); $1525(-\mathrm{N}=\mathrm{N}-)$, and 864 (aromatic substituted). ${ }^{1} \mathrm{H}-\mathrm{NMR}$ : 8/ppm $14.2(\mathrm{O}-\mathrm{H}, \mathrm{s}, 1 \mathrm{H}), \quad 9.95 \quad(\mathrm{CHO}, \mathrm{s}, 1 \mathrm{H})$, 7.8 (aromatic, m,7H), $3.9\left(\mathrm{OCH}_{3}, \mathrm{~s}, 3 \mathrm{H}\right) ; \mathrm{m} / \mathrm{z}: 256(30 \%)$, 179 (10\%), 151 (30\%), 77 (100\%).

\section{Synthesis of 2-methoxy-4-((phenylimino)methyl) phenol (3) \\ Vanillin $(0.28 \mathrm{~g}, 3 \mathrm{mmol})$ and ethanol $(25 \mathrm{~mL})$ was} introduced to the base-round three neck flask capacity $100 \mathrm{~mL}$ equipped with magnetic stirrer, a thermometer and condenser. Aniline $(0.46 \mathrm{~g}, 3 \mathrm{mmol})$ was added to the flask and refluxed for $30 \mathrm{~min}$. The result was cooled to room temperature and dried with anhydrous $\mathrm{Na}_{2} \mathrm{SO}_{4}$. Solvent was evaporated with evaporator Büchi and residue was added with aquadest until the precipitate formed. The precipitation was filtered and then dried in desiccators. The product was characterized as yellow powder $(82.17 \%)$, m.p. $150-152{ }^{\circ} \mathrm{C}$, IR $\mathrm{cm}^{-1}: 3500$ (O-H); $3086\left(\mathrm{C}_{\mathrm{sp}}{ }^{2}-\mathrm{H}\right.$ aromatic); $2900\left(\mathrm{C}_{\mathrm{sp} 3}-\mathrm{H}\right) ; 1581$ $(\mathrm{C}=\mathrm{N}) ; \quad 1512 \quad(\mathrm{C}=\mathrm{C}$ aromatic); 871 (aromatic substituted). ${ }^{1} \mathrm{H}-\mathrm{NMR}: \quad \delta / \mathrm{ppm} \quad 8.36 \quad(-\mathrm{CH}=\mathrm{N}, \mathrm{s}, 1 \mathrm{H})$; 7.6 ppm (O-H,s,1H); $7.27(\mathrm{Ar}, \mathrm{m}, 8 \mathrm{H}), 3.9\left(\mathrm{OCH}_{3}, \mathrm{~s}, 3 \mathrm{H}\right)$; m/z: 227 (100\%), 197 (10\%), 104 (20\%), 77 (80\%).

\section{Synthesis of 2-methoxy-6-(phenylazo)-4-((phenyl imino)methyl)phenol (1) \\ The compound of 4-hydroxy-3-methoxy-5-} (phenylazo)benzaldehyde $2(0.19 \mathrm{~g}(0.75 \mathrm{mmol}))$ and ethanol $(15 \mathrm{~mL})$ was introduced into the base-round three neck flask capacity $100 \mathrm{~mL}$ equipped with a magnetic stirrer, thermometers and condenser. Aniline $(0.07 \mathrm{~g}, 0.75 \mathrm{mmol})$ was added to the flask and refluxed for $30 \mathrm{~min}$. The result was cooled to room temperature. Solvent was evaporated with evaporator Büchi. The residue was added with aquadest and stirred until the precipitate formed. Precipitate was filtered and washed with aquadest and dried in desiccators. The product was obtained as brown powder $(82.21 \%)$, m.p. $144-146{ }^{\circ} \mathrm{C}$, IR $\mathrm{cm}^{-1}: 3433$ (O-H); $3070\left(\mathrm{C}_{\mathrm{sp}}{ }^{2}-\mathrm{H}\right.$ aromatic); $2931\left(\mathrm{C}_{\mathrm{sp} 3}-\mathrm{H}\right) ; 1627$ $(\mathrm{C}=\mathrm{N}), \quad 1589(\mathrm{~N}=\mathrm{N}) ; 1489 \quad(\mathrm{C}=\mathrm{C}$ aromatic); 864 
(aromatic substituted). ${ }^{1} \mathrm{H}-\mathrm{NMR}: \delta / p p m 14.0(\mathrm{O}-\mathrm{H}, \mathrm{s}, 1 \mathrm{H})$, 8.6 $(-\mathrm{CH}=\mathrm{N}, \mathrm{s}, 1 \mathrm{H}), 7.62(\mathrm{Ar}, \mathrm{m}, 8 \mathrm{H}), 4.1\left(\mathrm{OCH}_{3}, \mathrm{~s}, 3 \mathrm{H}\right)$.

Test for solution color change of 4-hydroxy-3methoxy-5-(phenylazo)benzaldehyde (2), 2-methoxy4-((phenylimino)methyl)phenol (3) and 2-methoxy-6(phenylazo)-4-((phenylimino)methyl)phenol (1)

Buffer solutions were prepared with variations of $\mathrm{pH}$ 2-13. The solution of 4-hydroxy-3-methoxy-5(phenylazo)benzaldehyde 2 was prepared by dissolving of compound $2(0.05 \mathrm{~g})$ in $5 \mathrm{~mL}$ of ethanol. Each buffer solution $(2.5 \mathrm{~mL})$ was put into a test tube and then added 2 drops of a solution of compound 2 . The same treatments were performed for compounds of 2methoxy-4-((phenylimino)methyl)phenol 3 and 2methoxy-6-(phenylazo)-4-((phenylimino)-methyl)phenol (1). Color change was recorded.

Test for color stability of compounds 2-methoxy-4((phenylimino)methyl)phenol (3) and 2-methoxy-6(phenylazo)-4-((phenylimino)methyl)phenol (1) in the acid

Titration of $\mathrm{NaOH}$ solution was performed with a solution of oxalic acid $\left(\mathrm{H}_{2} \mathrm{C}_{2} \mathrm{O}_{4}\right)$ at various concentrations in the Table 1 using indicators of 2-methoxy-4((phenylimino)methyl)phenol 3 and 2-methoxy-6(phenylazo)-4-((phenylimino)methyl)phenol 1. After equivalent point reached, the stability of change of color solution was recorded.

Test as a titration indicator of 2-methoxy-4((phenylimino)methyl)phenol (3) and 2-methoxy-6(phenylazo)-4-((phenylimino)methyl)phenol (1)

Titration was performed against $\mathrm{NaOH}$ solution using oxalic acid solution. The solution of $\mathrm{NaOH}$ was taken for $5 \mathrm{~mL}$ and added 2 drops of solution methoxy-24-((phenylimino)methyl)phenol 3. The solution was then titrated with standard solution of $0.05 \mathrm{M}$ oxalic acid until the color changes. The same treatment performed for 2methoxy-6-(phenylazo)-4-((phenylimino)methyl)phenol 1. Each titration was performed for three times and recorded the volume of a solution of $0.05 \mathrm{M}$ oxalic acid required for titration. The same treatment performed on phenolphthalein indicators as comparative indicators.

\section{RESULT AND DISCUSSION}

The target compound 1 was prepared by two methods as shown in Scheme 1.

Method 1, the target compound 1 has been obtained in good yield. The structure elucidation for the compound 1 has been indicated the existing of $\mathrm{C}=\mathrm{N}$ band $\left(1627 \mathrm{~cm}^{-1}\right)$ and $\mathrm{N}=\mathrm{N}$ band $\left(1589 \mathrm{~cm}^{-1}\right)$. The ${ }^{1} \mathrm{H}-\mathrm{NMR}$ also supported the existing of $-\mathrm{CH}=\mathrm{N}-$ peak ( $\delta 8.6 \mathrm{ppm})$. These spectra were really different compared
Table 1. Variation of $\mathrm{NaOH}$ concentration and $\mathrm{H}_{2} \mathrm{C}_{2} \mathrm{O}_{4}$ Indicator compounds

\begin{tabular}{cccc}
\hline $\begin{array}{c}\text { 2-methoxy-4- } \\
\text { (phenylimino)methyl) } \\
\text { phenol 3 }\end{array}$ & $\begin{array}{c}\text { 2-methoxy-6-(phenylazo)-4- } \\
\text { (phenylimino)methyl)phenol 1 }\end{array}$ \\
\hline$[\mathrm{NaOH}]$ & {$\left[\mathrm{H}_{2} \mathrm{C}_{2} \mathrm{O}_{4}\right]$} & {$[\mathrm{NaOH}]$} & {$\left[\mathrm{H}_{2} \mathrm{C}_{2} \mathrm{O}_{4}\right]$} \\
\hline $0.50 \mathrm{M}$ & $0.50 \mathrm{M}$ & $0.50 \mathrm{M}$ & $0.50 \mathrm{M}$ \\
$0.15 \mathrm{M}$ & $0.15 \mathrm{M}$ & $0.25 \mathrm{M}$ & $0.25 \mathrm{M}$ \\
$0.10 \mathrm{M}$ & $0.10 \mathrm{M}$ & $0.05 \mathrm{M}$ & $0.05 \mathrm{M}$ \\
$0.05 \mathrm{M}$ & $0.05 \mathrm{M}$ & - & - \\
\hline
\end{tabular}

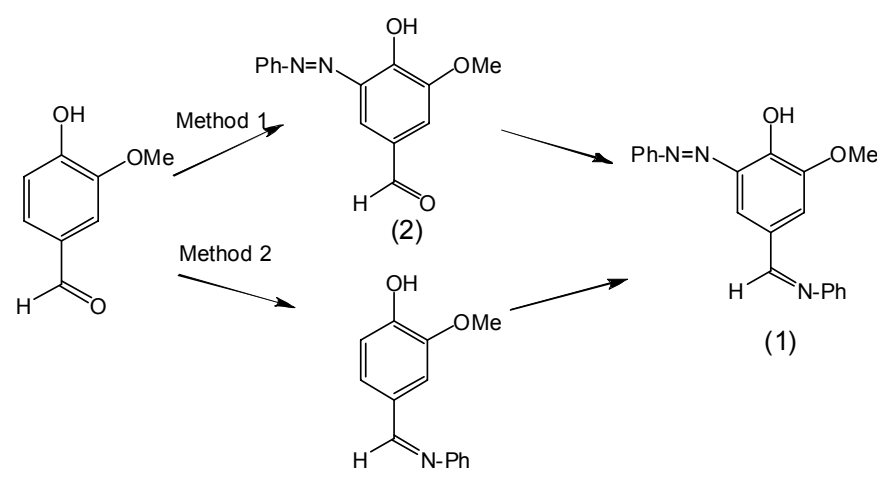

(3)

Method 1: i. Diazotization reaction, ii. Schiff base imine formation Method 2: i. Schiff base imine, ii. Diazotization

Scheme 1. Route synthesis to produce the target compound 1

spectra of compound 2. IR spectra indicated specific vibration for the $\mathrm{CHO}$ band $\left(1674 \mathrm{~cm}^{-1}\right)$ and $\mathrm{N}=\mathrm{N}$ band $\left(1525 \mathrm{~cm}^{-1}\right)$. The ${ }^{1} \mathrm{H}-\mathrm{NMR}$ showed the specific for $\mathrm{CHO}$ peak $(\delta \quad 9.95 \quad \mathrm{ppm}, \mathrm{s}, 1 \mathrm{H})$ and aromatic ( $\delta 7.8 \mathrm{ppm}, \mathrm{m}, 7 \mathrm{H})$. The molecular ion was indicated $\mathrm{m} / \mathrm{z}$ 256 corresponding molecular weight for compound 2.

Synthesis in method 2 has been started by formation of imine derivative. Compound 3 has been produced in good yield. The IR spectra of this compound showed very specific of $\mathrm{C}=\mathrm{N}$ band $\left(1581 \mathrm{~cm}^{-1}\right)$ and also supported by ${ }^{1} \mathrm{H}-\mathrm{NMR}$ spectra of $-\mathrm{CH}=\mathrm{N}$ - peak ( $\delta 8.36 \mathrm{ppm})$. The molecular ion was shown $\mathrm{m} / \mathrm{z} 227$ indicating molecular weight for compound 3. Following step of diazotization reaction produced compound 2 rather than compound $\mathbf{1}$. This reaction indicated that the imine group was hydrolyzed in acid condition during diazotization reaction. Hydrolysis mechanism could be predicted after formation of compound $\mathbf{1}$ then the imine group was converted to carbonyl derivative as a product of compound 2.

The color change of buffer solution at various $\mathrm{pH}$ after addition of solution of compound $\mathbf{2}$ showed light brown at $\mathrm{pH}<5$, light yellow at $\mathrm{pH} \mathrm{6-7} \mathrm{and} \mathrm{orange} \mathrm{at}$ $\mathrm{pH}>7$ as shown in Fig. 2. The color change of buffer solution at various $\mathrm{pH}$ after addition of solution of compound 3 showed colorless at $\mathrm{pH}<6$, yellowish at 

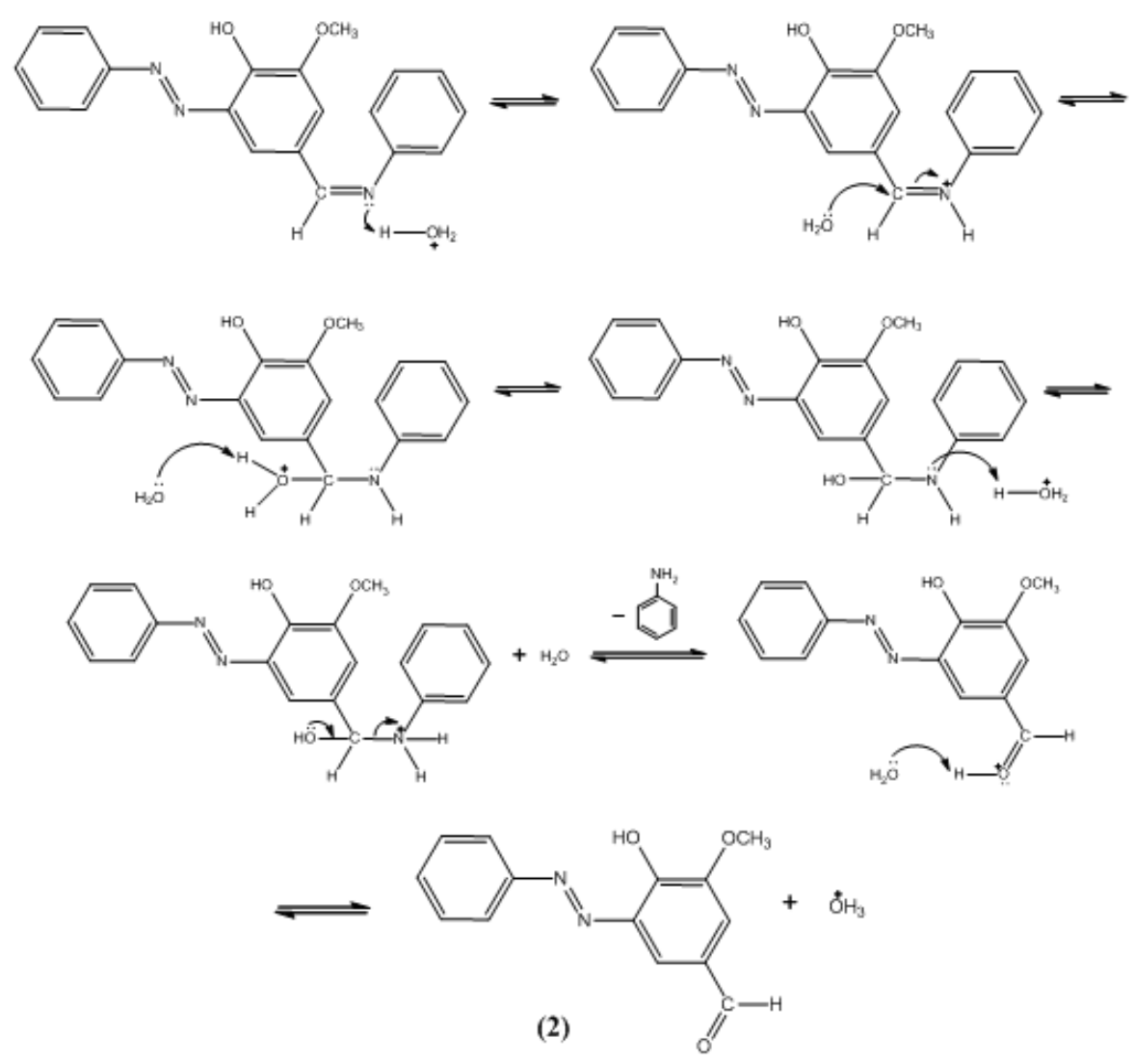
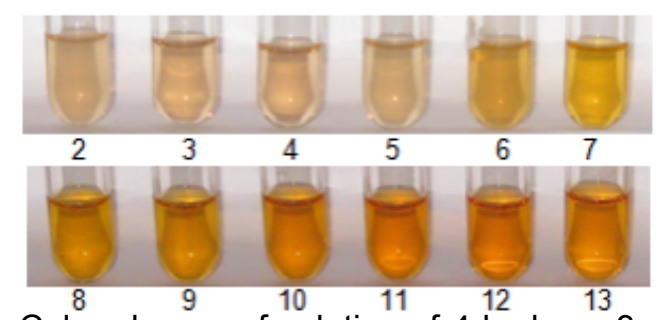

Fig 2. Color change of solution of 4-hydroxy-3-methoxy5 -(phenylazo)benzaldehyde (2) at various buffer solution with $\mathrm{pH} 2-13$

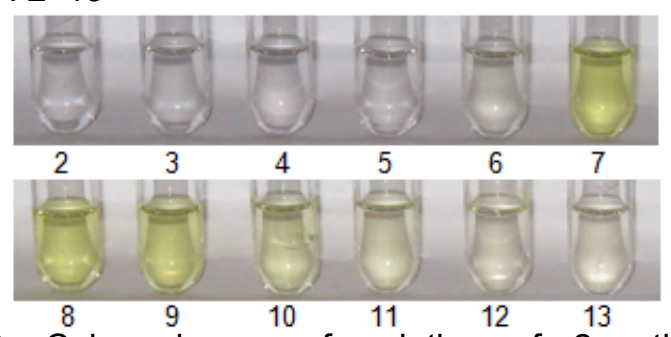

Fig 3. Color change of solution of 2-methoxy-4((phenylimino)methyl)phenol 3 at various buffer solution with $\mathrm{pH} 2-13$

$\mathrm{pH} 7-9$ and light green at $\mathrm{pH}>10$.

The color change of buffer solution at various $\mathrm{pH}$ after addition of solution of compound 1 showed light brown at $\mathrm{pH}<4$, yellow at $\mathrm{pH} \mathrm{5-8}$ and orange at $\mathrm{pH}>10$.
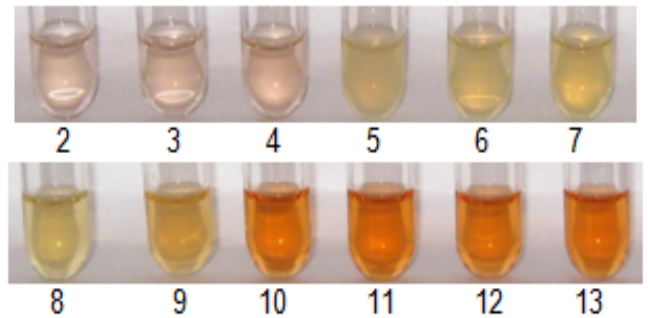

Fig 4. Color change of solution of 2-methoxy-6(phenylazo)-4-((phenylimino)methyl)phenol 1 at various buffer solution with $\mathrm{pH} 2-13$

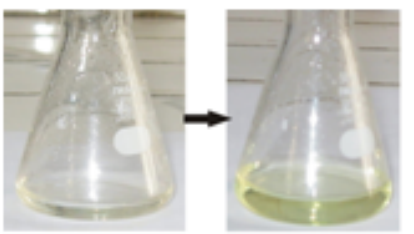

A

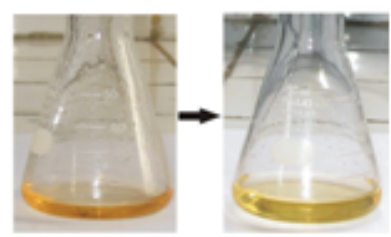

B
Fig 5. A. Color change with indicator compounds $\mathbf{3}$, and $\mathrm{B}$ color change with indicator compound $\mathbf{1}$

Based on this color change examination, compound $\mathbf{1}$ and $\mathbf{3}$ will be further examined for acidbase titration indicator compounds. Compound $\mathbf{2}$ failed to give sharp color change at range $1-2 \mathrm{pH}$ scale as a 
Table 2. Color stability after equivalent point for $\mathrm{NaOH}$ solution titrated by $\mathrm{H}_{2} \mathrm{C}_{2} \mathrm{O}_{4}$ solution

\begin{tabular}{cccccc}
\hline \multicolumn{2}{c}{ Concentration (M) } & \multicolumn{2}{c}{ Indicator compound 1 } & \multicolumn{2}{c}{ Indicator compound 3 } \\
$\mathrm{NaOH}$ & $\mathrm{H}_{2} \mathrm{C}_{2} \mathrm{O}_{4}$ & Color Change & $\begin{array}{c}\text { Color stability } \\
\text { (second) }\end{array}$ & Color Change & $\begin{array}{c}\text { Color } \\
\text { stability } \\
\text { (second) }\end{array}$ \\
\hline 0.50 & 0.50 & Orange to Yellow & Permanent & Light green to Yellowish & $2-3$ \\
0.25 & 0.25 & Orange to Yellow & Permanent & - & - \\
0.15 & 0.15 & - & - & Light green to Yellowish & 10.86 \\
0.10 & 0.10 & - & - & Light green to Yellowish & 63.93 \\
0.05 & 0.05 & Oranye to Yellow & Permanent & Light green to Yellowish & 100.98 \\
\hline
\end{tabular}

Table 3. Results of $\mathrm{NaOH}$ titration with $\mathrm{H}_{2} \mathrm{C}_{2} \mathrm{O}_{4}$ solution $(0.05 \mathrm{M})$ using phenolphthalein, compound 3 and 1 as titration indicators

\begin{tabular}{lcl}
\hline \multicolumn{1}{c}{ Indicator compounds } & $\begin{array}{c}\text { Average Volume of } \mathrm{H}_{2} \mathrm{C}_{2} \mathrm{O}_{4} \\
\text { solution }(\mathrm{mL}) \pm S . D\end{array}$ & \multicolumn{1}{c}{ Color change } \\
\hline $\begin{array}{l}\text { 2-methoxy-6-(phenylazo)-4- } \\
\text { (phenylimino)methyl)phenol (1) }\end{array}$ & $4.87 \pm 0.06$ & Orange to Yellow (Fig. 5B) \\
$\begin{array}{l}\text { 2-methoxy-4-((phenylimino)- } \\
\text { methyl)phenol (3) }\end{array}$ & $4.83 \pm 0.06$ & $\begin{array}{l}\text { Light green to Yellowish } \\
\text { (Fig. 5.A) }\end{array}$ \\
Phenolphthalein & $4.87 \pm 0.06$ & Pink to colorless \\
\hline
\end{tabular}

titration indicator $\mathrm{pH}$. Compound 1 will be tried for equivalent point at $\mathrm{pH} 6-8$ in acid-base titration while compound 3 will be examined for equivalent point at $\mathrm{pH}$ $7-9$.

\section{Color Stability Test}

Color stability was conducted by determining of discoloration time at equivalent point in titration. Since range of $\mathrm{pH}$ giving color change between 6-8 for compound 1 and 7-9 for compound 3, titration of $\mathrm{NaOH}$ solution with $\mathrm{H}_{2} \mathrm{C}_{2} \mathrm{O}_{4}$ solution will be chosen for examination of color stability at equivalent point. Various concentration both solutions has also been varied. Result of color stability of equivalent point for titration of $\mathrm{NaOH}$ solution with $\mathrm{H}_{2} \mathrm{C}_{2} \mathrm{O}_{4}$ solution has been recorded in Table 2.

From the Table 2, indicator compound 1 showed color stabilization up to $0.5 \mathrm{M}$ in this experiment. Compound $\mathbf{3}$ did not show color stabilization on equivalent point for range $\mathrm{H}_{2} \mathrm{C}_{2} \mathrm{O}_{4}$ concentration of $0.15-0.5 \mathrm{M}$ (short color stabilization less then $10 \mathrm{sec}$ ) but the color is stable enough for concentration up to $0.1 \mathrm{M}$.

\section{Application as an Acid-Base Titration Indicator}

Application of compound $\mathbf{1}$ and $\mathbf{3}$ as a titration indicator will be compared with standard indicator phenolphthalein in titration of $\mathrm{NaOH}$ solution with $\mathrm{H}_{2} \mathrm{C}_{2} \mathrm{O}_{4}$ solution $(0.05 \mathrm{M})$. The color change for titration was shown in figure 5 and result of titration has been written in Table 3.
Table 3 indicated that target compound 1 can be used as a acid-base titration indicators with same accuracy with phenolphthalein. For compound $\mathbf{3}$ has accuracy less than $0.81 \%$ compared with standard indicator of phenolphthalein.

\section{CONCLUSION}

The target compound 1 could be synthesized by reaction of vanillin with diazotitation then imine formation giving 2-methoxy-6-(phenylazo)-4((phenylimino)methyl)phenol. The target compound 1 could be used as titration indicator for titration of $\mathrm{NaOH}$ with $\mathrm{H}_{2} \mathrm{C}_{2} \mathrm{O}_{4}$ with same result using phenolphthalein indicator.

\section{REFERENCES}

1. Purwono, B., and Mahardiani, 2009, Indo. J. Chem., 9, 1, 95-98.

2. Khan, P.A. and Farooqui, M., 2011, J. Adv. Sci. Res., 2, 4, 20-27.

3. Kirkan, B., and Gup, R., 2008, Turk. J. Chem., 32, 9-17.

4. Al-Rubaie, L.A., and Mhessn, R.J., 2012, E-J. Chem., 9, 1, 465-470.

5. Carofiglio, T., Fregonese, C., Mohr, G.J., Rastrelli, F., and Tonellato, U., 2006, Tetrahedron, 62, 1502-1507.

6. Makedonski, P., Brandes, M., Grahn, W., Kowalsky, W., Wichern, J., Wiese, S., and Johannes, H-H, 2004, Dyes Pigm., 61, 2, 109-119.

7. Hinks, D., Freeman, H.S., Arai, Y., and Ando, H., 2001, Dyes Pigm., 48, 1, 7-13. 
8. Khalil, R.A., Jalil, A.H., and Abd-Alrazzak,A.Y., 2009, J. Iran. Chem. Soc., 6, 2, 345-352.

9. Ibrahim, M.N., and Sharrif, S.A.I., 2011, E-J. Chem., 8, 1, 180-184.
10. Noroozi-Pesyan, N., Khalafy, J., and Malekpoor, Z., 2009, Prog. Color Colorants Coat., 2, 1, 61-70.

11. Huang, Z., Wan, D., and Huang, J., 2001, Chem. Lett., 708-709. 